Hacer Nilay Suludere

UDC: 316.343:81'243

Ca' Foscari University of Venice

DOI: 10.18485/dh.2015.2.ch16

\title{
FLIPPED LEARNING AND LEARNER AUTONOMY
}

\begin{abstract}
Summary
Autonomous learners are usually credited with being good language learners. For this reason, it is important to understand the nature of autonomy and what it means in foreign/second language (L2) classes. By this way, L2 teaching can be informed to foster autonomy in classrooms. This study presents the importance of learner autonomy in L2 learning and argues flipped learning as a facilitator of learner autonomy in L2 classes. It also provides a prototype questionnaire devised by the author as a survey instrument in order to observe existence and/or gain of learner autonomy in flipped L2 classes.
\end{abstract}

Key words: flipped learning, learner autonomy

\section{Introduction}

People have learnt L2s for various reasons throughout history. Due to the changing requirements of time, not only learners, but also teachers have sought for meeting these needs. One such language requirement of increasing groups of immigrants in Europe around 1970s marked the introduction of Communicative Language Teaching (Savignon 263). The emphasis on communication in the new approach pushed the teacher back and put the learner in the center of learning. This caused a shift of attention from teacher to learner, which yielded important studies about motivation and ultimately learner autonomy.

\section{Learner Autonomy}

Learner autonomy which means to "take charge of one's own learning" (Holec 3 ) refers to the state of being able to take responsible actions to promote one's own learning. In other words, an autonomous learner 
is aware of his own learning and thus is capable of deciding and taking action according to his/her own needs like designing his/her own course plan, and adopting various learning styles and strategies by evaluating his/her learning process and progress. In a nutshell, an autonomous learner knows what and how to learn.

Yet, taking responsibility of one's own learning requires time and effort. Scharle and Szabo (9) describe the process of gaining autonomy in three phases: Firstly, learner needs to raise awareness about learning consciously. At this phase, teacher is of crucial important as $s /$ he is the active part in terms of guiding learners towards realization of their duties in the learning process. The second is practising the skills presented in the first phase to change attitudes. In this stage, teacher is always one step back in order to give more chances to the learners to initiate activities. The final stage is transferring some of the teacher roles to learners. It means adapting classroom management in a way that allows learners to be granted by a considerable amount of freedom in setting learning objectives and also by responsibilities in deciding about tasks to complete.

Though it is obvious that autonomous learners are independent, this does not mean that they are completely alone in their learning. They gain a realization of what would be necessary for them to learn (conscious way of reflecting on their needs) and how they learn (the strategies and styles) in order to benefit lessons in the best way. Thus, an authority, in most cases a teacher, is presented in autonomous learning. Little (81) draws a comprehensive frame around what autonomy is not by stating:

"Autonomy is not a synonym for self-instruction; in other words, autonomy is not limited to learning without a teacher. In the classroom context autonomy does not entail an abdication of responsibility on the part of the teacher; it is not a matter of letting the learners get on with things as best as they can. On the other hand, autonomy is not something that teachers do to learners; that is it is not another teaching method."

As for the ways of promoting learner autonomy in L2 classes, today one may immediately propose the use of technology. In theory, that is true. 
Yet, in practice technology becomes generally the aim of a course. A major part of learners today are left alone in their discovery of, say, news and videos in their original languages on the internet. They have the tools necessary to obtain information, but they are not capable of handling the information in a way that may allow them improve their knowledge. As Murray (cited in Reinders and White 1) argues what may avoid learners from taking more responsibility of their learning is the unrestricted access to information lacking of proper guidance and feedback.

Undoubtedly, each generation of learners are coming to schools more equipped with technological devices and technology skills than elder ones. The truth is that the more technology-driven challenges emerge, the more educators need to revise techniques and aims of pedagogy (Laurillard XVI). Thus, the function of technology as a tool to achieve goals of courses not the other way round is crucial. A carefully designed course aided by what technology offers may have the possibility of creating the optimum learning environment.

Flipped learning stands out as one of the results of this rethinking process. It can be said that it is the interpretation of the advent of new technologies to inform pedagogy. It considers technology as a tool to reach objectives of courses. In the L2 scope, it becomes more important, because the most outstanding premise it proposes is that it frees the class (face-to-face) time to promote hands-on experiment of material, target language, by having learner study it out of the class through previously captured video lessons by teacher. Considering that teachers are usually the main and in most cases the only actors in L2 classrooms to supply feedback on progress of learning, the freed class time can present teachers the opportunity to attend to their students individually.

\section{The Flipped Classroom Model}

Although flipped learning concept seems recent, attributed mostly to Jonathan Bergmann and Aaron Sams who tried teaching their subject matters via recording video lessons, making them available to their students before class time, and using the class time to work with their students on the material in 2007 , it can be traced well back to 1995, when 
J. Wesley Baker started to have his students read slides of lessons before coming to class. According to Strayer (172) flipped learning can be said to have existed for decades as teachers asked their students to read course materials and discuss them at a deeper level in the classroom.

Before continuing with the details of flipped learning, it is important to sort out the misconceptions regarding the terms inverted learning, flipped learning and flipped classroom. First of all, in the majority of the state of art, all of the terms are used interchangeably. Yet, according to the Flipped Learning Network ${ }^{1}$, which is founded by key leaders in the field, flipped learning differs from flipped classroom. They claim that "flipping a class can but not necessarily, lead to flipped learning. Many teachers may already flip their classes by having their students read text outside of class, watch supplemental videos, or solve additional problems, but to engage in flipped learning, teachers must incorporate the following four pillars into their practice". The first of these four pillars provided by the website is flexible environment which refers students' preferences of where and when to learn. The second is learning culture by which learner-centered active learning is intended. The third pillar is the intentional content. According to the website educators should decide what learners need to learn and to what extent they should explore it on themselves. The last pillar is the professional educator and as its name stands it means educators who detect when to help learners and supply feedback as well as are open to criticism aimed at improvements and work collaboratively with other educators. Without these conditions met flipped learning does not occur.

The term flipped classroom which includes all the pillars mentioned above basically refers to shifting instruction to homework and vice versa. That is, the traditional roles of homework and lecture are reversed (Lage, Platt and Treglia 32). In a traditional classroom the scene is expected to look like that a teacher talks to whole class and instructs directly in limited time and assigns tasks to do as homework. The flipped classroom model literally flips the traditional classroom. In other words, material learning is done out of classroom and homework which requires practice of material learnt is done in classroom with the guidance of teacher through interactive learner-centered activities.

http://flippedlearning.org/domain/46 


\section{Flipped Classroom Model as a Trigger for Autonomous Learning}

In a flipped classroom the organization of teaching and learning changes with respect to a traditional classroom. Thus, the roles and the responsibilities of both teachers and their students undergo changes (Bergmann and Sams ch. 2). To begin with, teachers are expected to provide suitable and well-organized materials in advance. They may either create their own materials like videos and podcasts through their own means or make use of already prepared ones (mostly available to public on websites like The Khan Academy², MIT OpenCourseWare ${ }^{3}$ and Coursera $\left.^{4}\right)$. Moreover, they are responsible for preparing out-of-classroom selflearning activities which are associated with content that encourage students to know more about the material. These self study activities also helps to ensure that learners pay attention to content they are studying. Besides them, teachers have to devise neatly class time activities aiming at parts that students may need the most help to understand and process content. During class time, teachers should not re-teach the material, but briefly discuss it with whole class, clarify doubts, introduce extra resources and be guides and assistants who supply feedbacks.

As it can be seen, the features of an autonomous learning environment are fitted in a flipped classroom. First of all the flipped classroom model frees the class time for more interaction among students and between students and teachers. This leads teachers "have the ability to check, monitor, re-direct and mentor the individual at each class meeting" (Larcara 136). In this way, learning becomes personalized and students are not alone in their out-of-classroom learning. Individual students can always go back and study archived lecture videos whenever and wherever they want (Bergmann and Sams ch.3). This individualized kind of learning provides students with the option to decide amount of time they need to learn content. They can rewind videos as many times as they need to master a subject. Driscoll and Petty (121) state that archived instruction can also be applied as a remediation by students who need repetition to complete complex tasks. Moreover, the control over the learning time,

2 https://www.khanacademy.org/

3 http://ocw.mit.edu/index.htm

4 https://www.coursera.org/ 
the selection of the way to demonstrate mastery of an objective of the lesson and the decision of the time to seek teacher guidance grant the students with autonomy (Driscoll and Petty 122-126).

\section{An Instrument to Measure Learner Autonomy}

Measuring learner autonomy is a difficult task. Developing an instrument to measure it is much more difficult. Although various studies attempting to measure learner autonomy have been carried out, none has brought forward a totally developed measuring instrument yet (e.g. Cotteral; Mynard; Macaskill and Taylor). Bachman (32) suggests that "all measures of mental ability are necessarily indirect, incomplete, imprecise, subjective, and relative". This explains why, for the time being, tools provided by science to measure such an abstract concept as learner autonomy seem to be limited to being qualitative. With this premise in mind, Mynard's (4-5) grouping of the approaches to measuring learner autonomy that are listed below seems legitimate.

1. Interpretative research approaches

2. Small-scale research and first person narratives

3. Interviews

4. Learner journals

5. Observation

6. Frameworks

7. Researching without a framework.

As it is seen, a plenty of approaches to measuring learner autonomy are interpretative and requires qualitative research methods. In spite of the fact that findings obtained from studies based on these approaches may not be used for generalizations, they give precious insights regarding such a complex and indefinite concept. As Mynard (5) puts forward "it is far more beneficial to describe and discuss evidence of learning autonomy in a given context rather than attempt to measure it".

\section{Devising a Questionnaire as an Instrument}

Concerning the limits of measuring learner autonomy in general, a questionnaire that can prove the existence of learner autonomy in a 
flipped L2 classroom may be more beneficial to understand its nature and how it emerges in classes in which this model is conducted. The discussion above presents clues regarding possible positive effects of introducing the flipped classroom model in L2 teaching on promoting learner autonomy. In order to unfurl what really goes on in a flipped L2 classroom in terms of autonomous learning, a descriptive questionnaire may serve better than any other instrument. Yet, in order to provide reliability and indirectly validity of such a qualitative questionnaire, there is also the need for descriptors of autonomous learning to base the questionnaire.

In the literature on learner autonomy one such basis can be found. Lee (1998) proved and explained five factors that foster learner autonomy in language learning. These factors can be exploited as the descriptors for a questionnaire which aims to prove the existence and nature of learner autonomy in a flipped classroom. These five factors are:

1. voluntariness (pre-requisite for autonomous learning)

2. learner choice (making decisions, setting objects, evaluating learning)

3. flexibility (supportive environment for autonomous learning)

4. teacher support (providing feedback and guidance)

5. peer support (collaboration with other individuals/learners)

The following questionnaire (Appendix $A$ ) is a prototype which was devised by the author based on these five factors to trace autonomous learning in a flipped L2 classroom. It is to be given at the end of an L2 course which conducted the flipped classroom model to intermediate level teenagers/adults. The questionnaire consists of three parts. The first part, Part A, provides the background information about learners. This part is useful to understand if students did all the requirements of the flipped learning. In this way, the implementer of the questionnaire can eliminate the questionnaires which inform that although lessons have been flipped, the students have not reflect them in their studies properly. The Part B includes the items carefully written to respond to the factor categories. The implementer should extract keywords from responses by using content analysis methods and interpret each response and decide which factor category it suits. In the end, a big picture demonstrating what categories are outstanding can be obtained and this information 
can be used to interpret what aspects of autonomous learning might have been fostered by flipped classroom model. The final part, Part C, explores in depth the learners' thoughts to understand better in what ways the flipped classroom model intervenes with learner autonomy. Again, the implementer should interpret completed statements to find out which factor is inhibited through flipped learning. After pre-testing and piloting, the items that do not make sense to learners can be eliminated and/or improved. Consequently, problems regarding the aims of the questionnaire can be solved.

At the end of analysis, a comprehensive framework of emerging factors that promote autonomous learning in a flipped $L 2$ classroom can be drawn and later be used for comparison and improvement reasons.

\section{Conclusions}

Learner autonomy plays an important role in learning an $L 2$, particularly in the recent $L 2$ teaching approaches that put learner in the center of learning. Autonomous learners are aware of the whole learning process and as a result learning turns into a meaningful occupation for them. For this reason, it is important to promote autonomous learning in L2 classes. One possible way of promoting it can be conducting the flipped classroom model in L2 teaching. The model removes direct instruction from classroom to out of classroom mostly by means of teacher-created videos. Consequently, freed classroom time is used for meaningful learning and interactive practice of content by engaging students actively. In the flipped classroom model students are expected to take action for their own learning by studying material outside of classroom until they learn it and come to classroom to participate actively in classroom activities. They are expected to realize what they know and decide if they need further help from their teacher.

Although it seems that the flipped classroom model provides the base which can support the emergence of autonomous learning, it is not easy to measure to what degree it can. Learner autonomy cannot be referred by increasing or decreasing numbers. Yet, it is possible to infer if it is existing or gained. A questionnaire as an instrument to evidence any gain 
of learner autonomy may unfurl if the flipped classroom model really promotes autonomous learning, in what ways and how. A questionnaire of this kind should be able to trace the characteristics of autonomous learners and factors already presented in previous studies that yield autonomous learning. Interpretations of such questionnaires can offer a deeper understanding of the nature learner autonomy in flipped L2 classrooms.

\section{Appendix A}

This questionnaire was devised to explore learner autonomy in a flipped foreign/second language classroom. Thank you for your contribution.

Name and Surname of the Implementer:

Date

PART A: Please tick the answer that applies to you.

\begin{tabular}{|l|l|l|}
\hline I... & YES & NO \\
\hline 1. watched all the videos. & & \\
\hline 2. did all the tasks assigned for home study. & & \\
\hline 3. attended all the classroom activities. & & \\
\hline
\end{tabular}

PART B: Please tick the answer that applies to you and explain why.

\begin{tabular}{|l|l|l|l|}
\hline I felt... & YES & NO & BECAUSE \\
\hline 4. being engaged all the time in the whole learning process. & & & \\
\hline 5. alone when I was watching videos. & & & \\
\hline 6. the support of my friends in my learning. & & & \\
\hline 7. that it was easy to follow video lessons. & & & \\
\hline 8. that I enjoyed during the course. & & & \\
\hline 9. that I helped my friends in their learning & & & \\
\hline
\end{tabular}

PART C: Please complete the sentences according to your thoughts.

During the course...

10. I needed my teacher most when

11. The most disappointing thing was.

12. I felt that I benefited mostly from.

13. I think I would have benefited more if.

14. One advantage of the video lessons was..... 
15. One disadvantage of the video lessons was

16. I watched the videos most of the time on (write the technological device you used

17. I watched the videos most of the time (write where)

18. My overall thought about this course is

19. I learnt particularly very well because

20. I had difficulty in learning. because

\section{Works Cited}

Bachman, Lyle F. Fundamental Considerations in Language Testing. Oxford: Oxford University Press, 1990. Print.

Bergmann, Jonathan, and Aaron Sams. Flip Your Classroom: Reach Every Student in Every Class Every Day. First Edition. Eugene, Oregon: International Society for Technology in Education, 2012. Print.

Cotterall, Sara. "Promoting Learner Autonomy through the Curriculum: Principles for Designing Language Courses." ELT Journal 54.2 (2000):109-117. Web. 12 Apr. 2015.

Driscoll, Thomas F., and Katherine A. Petty. "Student-Driven Education with Flipped Learning and 20-Time." Practical Applications and Experiences in K-20 Blended Learning Environments. Eds. Lydia Kyei-Blankson, and Esther Ntuli. Hershey, PA: IGI Global, 2014. 120-136. Print.

Holec, Henri. Autonomy in Foreign Language Learning. Oxford: Pergamon, 1981. Print.

Lage, Maureen J., Glenn J. Platt, and Michael Treglia. "Inverting the Classroom: A Gateaway to Creating an Inclusive Learning Environment." The Journal of Economic Education. 31.1 (2000): 30-43. Web. 17 Feb. 2014.

Larcara, Marie. "Benefits of the Flipped Classroom Model." Promoting Active Learning through the Flipped Classroom Model. Eds. Jared Keengwe, Grace Ounchwari, and James N. Oigara. Hershey, PA: IGI Global, 2014. 132-144. Print.

Laurilliard, Diana. "Foreword to Second Edition."Rethinking Pedagogy for a Digital Age: Designing for $21^{\text {st }}$ Century Learning. Second Edition. Eds. Helen Beetham, and Rhona Sharpe. New York, NY: Routledge, 2013. Print.

Lee, Icy. "Supporting Greater Autonomy in Language Learning." ELT Journal 52.4 (1998):282-289. Web. 9 Apr. 2015.

Little, David. "Autonomy in Language Learning." Autonomy in Language Learning. Ed. Ian Gathercole. London: CILT, 1990. 7-15. Print.

Macaskill, Ann, and Elissa Taylor. "The Development of a Brief Measure of Learner Autonomy in University Students." Studies in Higher Education 35.3 (2010):351359. Web. 12 Apr. 2015. 
Murray, Denise E. "Access to Information Technology: Considerations for Language Educators." Prospect 14.3 (1999):4-12. Web. 20 Feb. 2014.

Mynard, Jo. "Measuring Learner Autonomy: Can it be done?." Independence Newsletter of the IATEFL Learner Autonomy Special Interest Group 37 (2006):3-6. Web. 5 Dec. 2015.

---. "Investigating Evidence of Learner Autonomy in a Virtual EFL Classroom: A Grounded Theory Approach" Research in ELT: Proceedings of the International Conference 9-11 Apr. 2000. Eds. J. Hull, J. Harris, P. Darasawang. Thonburi, Thailand: School of Liberal Arts and the Continuing Education Center, King Mongkut's University of Technology, 2004. 117-127. Web. 17 Mar. 2016.

Reindeers, Hayo, and Cynthia White. "Learner Autonomy and New Learning Environments." Language Learning and Technology 15.3 (2011):1-3. Web. 10 Nov. 2014.

Scharle, Agota, and Anita Szabo. Learner Autonomy: A Guide to Developing Learner Responsibility. Cambridge: Cambridge University Press. 2000. Print.

Savignon, Sandra J. "Communicative Language Teaching: State of Art." TESOL Quarterly 25.2 (1991):261-277. Web. 12 Apr. 2015.

Strayer, Jeremy F. "How Learning in an Inverted Classroom Influences Cooperation, Innovation and Task Orientation." Learning Environment Research 15 (2012):171193. Web. 12 Apr. 2015. 